\title{
Oxytocin, plasma containing leukocytes or combination of both as treatment of postbreeding endometritis in the horse
}

\author{
R.C. Mattos', Luciana Silva Meirelles', E. Malschitzky', L.F.F. Castilho², Adriana Pires Neves', Ana Luiza Gelpi Mattos'3, \\ Magda Jöchins Vieira', Andrea Keller', A.K. Hött' and R.M. Gregory'
}

Reprolab, Departamento de Medicina Animal, Faculdade de Veterinária, Universidade Federal do Rio Grande do Sul, Porto Alegre, RS, Brazil

Medicina Veterinária, AGROPLAC, Universidade do Planalto Central, Brasilia, DF, Brazil.

${ }^{3}$ Departamento de Medicina Veterinária, Centro de Ciâncias da Saúde, ULBRA, Canoas, RS, Brazil

\begin{abstract}
Summary
A total of 342 breeding cycles [262 lactating (L), 80 barren (B)] in 237 mares were evaluated. The effect of the following variables on pregnancy ( 14 and 42 days) was analysed using a general linear model system. Each cycle was randomly assigned to one of the following treatments: untreated control (T1); oxytocin (20 IU, i.v.), administered 0 and 12 to $16 \mathrm{~h}$ after breeding (T2); intrauterine infusion of leukocyte-enriched plasma (120 ml) 12 to $16 \mathrm{~h}$ after breeding (T3); combined treatment of oxytocin (20 IU, i.v.) administered $0 \mathrm{~h}$ after breeding and leukocyte-enriched plasma infused $12-16 \mathrm{~h}$ after breeding/insemination The early pregnancy rate per cycle was significantly higher $(\mathrm{p}<0.05)$ in barren mares treated with plasma containing leukocytes (78.6\%) than in mares treated with oxytocin (50.0\%) and in control mares $(52.0 \%)$, but they did not differ from pregnancy rates obtained in mares treated with the combined treatment $(69.2 \%$, T4). The different treatments $(T 2, T 3, T 4)$ did not affect significantly $(p>0.05)$ the pregnancy rate per cycle in lactating mares when compared to control group. it was concluded that the infusion of leukocyte-enriched plasma improves pregnancy rate per cycle in barren mares.
\end{abstract}

Keywords:

equine, postbreeding therapy, leukocytes, oxytocin

Oxytocinapplikation und leukozytenhaltige Plasmainfusion sowie Kombinationen beider Verfahren zur Endometritisbehandlung nach der Belegung beim Pferd

Ziel der Arbeit ist es, den Effekt von Oxytocin oder infundiertem leukozytenangereichertem Plasma bzw. deren Kombination auf die durch die Belegung hervorgerufene Endometritis zu ermitteln. Untersucht wurden insgesamt 342 Zyklen (laktierend: $n=263 ;$ güst: $n=80$ ) von 237 Stuten. Eine Trächtigkeitsuntersuchung erfolgte am 14. und 40. Tag post ovulationem, die Ergebnisse wurden anhand des allgemeinen linearen Modells statistisch analysiert. Die Stuten wurden randomisiert folgenden Behandlungsgruppen zugeteilt: T1: keine Behandlung Kontrolle, T2: Oxytocinapplikation (20 IU, i.v.) 0 und 12-16 Stunden nach der Belegung, T3: intrauterine Infusion von $120 \mathrm{ml}$ leukozytenangereichertem Plasma 0 und 12-16 Stunden nach der Belegung, T4: Oxytocinapplikation (20 IU, i.v.) 0 Stunden nach der Belegung und Infusion von leukozytenangereichertem Plasma 12-16 Stunden nach der Belegung.

Bei güsten Stuten, die mit einer leukozytenangereicherten Plasmainfusion behandelt worden waren, war die Trächtigkeitsrate $\langle 78,6 \%)$ signifikant höher $(p<0,05)$ als die der Kontrollen $(52,0 \%)$ und die derjenigen Stuten, bei denen Oxytocin appliziert worden war, unterschied sich jedoch nicht von der Rate, die nach Kombinationstherapie erzielt wurde $(69,2 \%)$. Bei Stuten mit Fohlen bei Fuß führte im Vergleich mit den Kontrollen keine der durchgeführten Behandlungen zu einer Anhebung der Trächtigkeitsrate $(p>0,05)$. Es wird die Schlußfolgerung gezogen, daß bei güsten Stuten die Trächtigkeitsrate pro Zyklus durch eine Infusion mit leukozytenangereichertem Plasma erhöht werden kann.

Schlüsselwörter: Pferd, postinseminale Therapie, Leukozyten, Oxytocin

\section{Introduction}

Reproductive efficiency in horses is low compared to other domestic species, with yearly pregnancy rates ranging from 50 to $60 \%$ (Ginther, 1992). Maintenance of a uterine environment compatible with embryonic and fetal life is necessary to improve fertility (Asbury, 1987). Contamination of the uterus with micro-organism during breeding or parturition can lead to inflammation of the endometrium, which disrupts the uterine environment and is detrimental to fertility. A transient acute endometritis commonly occurs after breeding or artificial insemination, as a result of an inflammatory reaction against bacteria and spermatozoa (Kotilainen et al., 1994; Troedsson et al., 1995). This should be considered as a physiological process that leads to the removal of excess spermatozoa, seminal plasma and contaminants prior to the ent- ry of the embryo into the uterus (Troedsson, 1997). In fertile mares resistant to endometritis, fast clearance of contaminants from the uterus causes this postbreeding endometritis to subside within a few hours or days. In contrast, mares susceptible to endometritis have high embryonic mortality and poor pregnancy rates because they are unable to completely clear contaminants from the uterus.

Several postbreeding treatments to improve fertility have been recommended. These treatments are intended to reduce uterine inflammation and contamination, restoring a uterine environment capable of supporting pregnancy. Treatments include antibiotics, uterine lavages, uterotonic drugs, and infusion of homologous plasma enriched or not with leukocytes. 
Objective was to determine whether postbreeding treatment of barren and lactating mares with an intrauterine infusion of plasma with leukocytes, oxytocin, or a combination of both would improve pregnancy rates.

\section{Materials and methods}

\section{Animals}

Estrous cycles $(n=342)$ of 237 mares were used. Lactating and barren mares accounted for 262 and 80 cycles, respectively. Barren mares were classified as susceptible or resistant to endometritis prior to treatment. History of recurrent endometritis was the criterion used to classify mares as susceptible.

\section{Plasma with leukocytes}

Blood $(270 \mathrm{ml})$ was collected from the jugular vein into a graduated cylinder containing anticoagulant (heparin, $10 \mathrm{lU} / \mathrm{ml}$ of blood) $1 \mathrm{~h}$ prior to infusion of plasma. Spontaneous separation of plasma from blood cells was allowed to occur. A solution of dextrose $(100 \mathrm{ml}, 6 \% \mathrm{w} / \mathrm{v})$ was added slowly to the separated blood to cause floatation of leukocytes into the plasma fraction. Floatation occurs within $30 \mathrm{~min}$ of addition of dextrose. The plasma fraction with leukocytes (> 5000 leukocytes $/ \mathrm{mm}^{3}$ ) was aspirated and infused immediately into the uterus.

\section{Reproductive management}

Teasing for detection of estrus was performed daily. When estrus was detected, mares were submitted to daily examinations of the uterus and ovaries by rectal palpation and $\mathrm{ul}$ trasonography. Ovarian structures observed were recorded in every examination. When a preovulatory follicle $(>35 \mathrm{~mm})$ was detected, examinations were ceased and mares were either naturally bred or artificially inseminated. Semen collected for artificial insemination was extended with skim milk $(1+2$, semen/extender). Insemination dose contained at least $500 \times 10^{6} \mathrm{sperm} / \mathrm{ml}$, and concentration of sperm ranged from $25 \times 10^{6}$ to $50 \times 10^{6} / \mathrm{ml}$.

\section{Treatments}

Each cycle was randomly assigned to one of the following treatments: untreated control (T1); oxytocin (20 IU, i.v.) administered 0 and 12 to $16 \mathrm{~h}$ after breeding (T2); intrauterine infusion of plasma with leukocytes $(120 \mathrm{ml}) 12$ to $16 \mathrm{~h}$ after breeding (T3); combined treatment of oxytocin (20 IU, i.v.) administered $\mathrm{O} h$ after breeding and plasma with leukocytes infused 12 to $16 \mathrm{~h}$ after breeding or insemination. Breeding and treatments were repeated every $48 \mathrm{~h}$ until ovulation was detected.

Pregnancy diagnosis was performed by ultrasonography 14 and 40 days (d14 and d40) after ovulation (d0). Embryonic loss was calculated using the difference between pregnancy rates detected on d14 and d40. Mares diagnosed open were randomly reassigned to a treatment and treated in the following estrus.

\section{Statistical analysis}

Data were analysed using chi-square and logistic regression analyses. The dependent variable was pregnancy rate at $\mathrm{d} 14$ and independent variables included treatment, age, history of endometritis, and method of breeding. Analysis of variance was used to test the effect of age. Means were compared using Tukey's test, and differences were considered significant at $P=0.05$.

\section{Results}

Mean age of lactating mares was $8.9 \pm 3.4$ years. Mean age of lactating mares in the different treatment groups did not differ $(P>0.05)$. Barren mares in T3 were older than mares in T1 (12.2 \pm 4.4 vs. 8.8 \pm 3.4 years, $P<0.05)$. Age of barren mares in T2 (10.1 \pm 4.0 years) and T4 $(10.2 \pm 3.9$ years) did not differ from age of mares in T3 and T1.

Pregnancy rates of lactating mares and barren mares on d14 were $54.3 \%$ and $63.8 \%$, respectively (table 1).

Tab. 1: Day 14 pregnancy rates according to treatment in barren and lactating mares

Trächtigkeitsrate am Tag 14 in Abhängigkeit von der Therapie güster und laktierender Stuten.

\begin{tabular}{|l|cc|cc|}
\hline Treatments & \multicolumn{2}{|c|}{ Barren Mares } & \multicolumn{2}{|c|}{ Lactating Mares } \\
& $\mathbf{n}$ & $\%$ & $\mathbf{n}$ & $\%$ \\
\hline T1 (Control) & 25 & $52.0^{\mathrm{a}}$ & 84 & $63.1^{\mathrm{a}}$ \\
\hline T2 (Oxytocin) & 10 & $50.0^{\mathrm{a}}$ & 54 & $42.6^{\mathrm{b}}$ \\
\hline T3 (plasma+leukocytes) & 28 & $78.6^{\mathrm{b}}$ & 73 & $54.8^{\mathrm{ab}}$ \\
\hline $\begin{array}{l}\text { T4 (plasma +leukocytes } \\
\text { +oxytocin) }\end{array}$ & 17 & $64.7^{\mathrm{ab}}$ & 51 & $47.1^{\mathrm{b}}$ \\
\hline
\end{tabular}

$a, b$ means within columns bearing different superscripts differ $(p<0.05)$

Pregnancy rates on day 14 of susceptible and resistant mares are presented in table 2 .

Tab. 2: Day 14 pregnancy rates according to treatment and susceptibility to endometritis

Trächtigkeitsrate am Tag 14 in Abhängigkeit von der Therapie und der Empfänglichkeit der Endometritiden.

\begin{tabular}{|l|cc|cc|}
\hline Treatments & \multicolumn{2}{|c|}{ Barren Mares } & \multicolumn{2}{|c|}{ Lactating Mares } \\
& $\mathbf{n}$ & $\%$ & $\mathbf{n}$ & $\%$ \\
\hline T1 (Control) & 9 & $33.3^{\mathrm{a}}$ & 11 & $54.5^{\mathrm{a}}$ \\
\hline T2 (Oxytocin) & 5 & $40.0^{\mathrm{a}}$ & 3 & $66.7^{\mathrm{ab}}$ \\
\hline T3 (plasma+leukocytes) & 13 & $69.2^{\mathrm{b}}$ & 12 & $83.3^{\mathrm{b}}$ \\
\hline $\begin{array}{l}\text { T4 (plasma +leukocytes } \\
\text { +oxytocin) }\end{array}$ & 8 & $50.0^{\mathrm{ab}}$ & 7 & $71.4^{\mathrm{b}}$ \\
\hline
\end{tabular}

$a, b$ means within columns bearing different superscripts differ $(p<0.05)$ 
Mares were either bred naturally or artificially inseminated. Pregnancy rates obtained using the two breeding methods are presented in table 3.

Tab. 3: Day 14 pregnancy rates according to treatment and breeding method

Trächtigkeitsrate am Tag 14 in Abhängigkeit von der Therapie und der Zuchtmethode.

\begin{tabular}{|l|cc|cc|}
\hline Treatments & \multicolumn{2}{|c|}{$\begin{array}{c}\text { Artificial } \\
\text { Insemination } \\
\text { n }\end{array}$} & \multicolumn{2}{c|}{$\begin{array}{c}\text { Natural } \\
\text { breeding } \\
\%\end{array}$} \\
\hline T1 (Control) & 69 & $65.2^{\mathrm{aA}}$ & 9 & $33.3^{\mathrm{aB}}$ \\
\hline T2 (Oxytocin) & 40 & $35.0^{\mathrm{bA}}$ & 8 & $50.0^{\mathrm{bA}}$ \\
\hline T3 (plasma+leukocytes) & 61 & $55.7^{\mathrm{aA}}$ & 10 & $60.0^{\mathrm{bA}}$ \\
\hline $\begin{array}{l}\text { T4 (plasma +leukocytes } \\
\text { +oxytocin) }\end{array}$ & 38 & $36.8^{\mathrm{bA}}$ & 11 & $72.7^{\mathrm{bB}}$ \\
\hline
\end{tabular}

a,b means within columns bearing different superscripts differ $(p<0.05)$ A,B means within rows bearing different superscripts differ $(p<0.05)$

Embryonic mortality between $\mathrm{d} 14$ and $\mathrm{d} 40$ of pregnancy in barren mares (12.0\%) and in lactating mares (22.8\%) did not differ $(P>0.05)$. Treatments did not affect embryo mortality $(P>0.05)$. Pregnancy rate of mares bred during foal heat $(n=112)$ was $24.0 \%(n=18)$.

\section{Discussion}

Pregnancy rates of untreated barren mares (T1) was lower than those of treated mares $(52 \%$ vs. $69,1 \%)$. However, pregnancy rates of untreated lactating mares (T1) were higher $(63.1 \%)$ than those of treated mares. This suggests that treatments improve pregnancy rates in barren mares but not in lactating mares.

Use of oxytocin alone in barren mares did not improve pregnancy rates relative to the control group. However, results were improved when oxytocin (T2) was used in combination with plasma with leukocytes (T3). The highest pregnancy rates were obtained when plasma with leukocytes was used (T3, 75\%). So, oxytocin (T2) not only did not improve pregnancy rates when used alone, but also reduced pregnancy rates when combined with plasma and leukocytes (T4).

These results are reinforced by the fact that mares treated with plasma with leukocytes (T3) were older than those in the other groups $(P>0.05)$. Older mares have decreased fertility Nanderwall and Woods, 1992) due to degenerative and inflammatory lesions of the endometrium (Bracher et al., 1997; Schoon et al., 1997), to increased embryonic mortality (Woods et al., 1987), to a greater tendency to accumulate fluid in the uterus, and to a reduced uterine contractility (Carnevale et al., 1993). Pregnancy rates obtained with plasma with leukocytes (T3) were significantly higher than those of the other treatment groups.

Pregnancy rates in susceptible barren mares treated with plasma with leukocytes (T3) were higher than those of untreated resistant mares $(T 1)$. Similarly, pregnancy rates were also improved in resistant mares treated with plasma with leukocytes (T3) and/or with plasma with leukocytes and oxytocin (T4). This suggests that resistant mares may have failures of the uterine defence mechanisms.

Greater pregnancy rates observed in mares treated with plasma with leukocytes (T3) are probably due to an improvement in opsonization and phagocytosis, which caused a faster clearance of pathogenic bacteria. The supplemental opsonins present in plasma may have allowed increased opsonization of micro-organisms by phagocytes already present in the uterus and by those infused with plasma. Neutrophils obtained from peripheral blood are fully functional (Liu et al., 1985). Separation of leukocytes using a $6 \%$ dextrose solution causes adhesion of platelets to neutrophils. Presence of platelets in the infused plasma may have increased phagocytic activity and inhibited leukocyte death by apoptosis (Zalavary et al., 1996; Andonegui et al., 1997).

Infusion of fluid into the uterus can also stimulate myometrial contractions (Jones, 1995). Indeed, the uterus tends to eliminate any infused content. In the case of plasma, myometrial contractility may be stimulated by proteins and sugars, or by prostanoids secreted by neutrophils activated during inflammation (Troedsson et al., 1993a). Infusion of dextrose, used in the separation of leukocytes, could reduce uterine inflammation and prevent bacterial adhesion. Infusion of 5\% mannose in the uterus has been shown to prevent bacterial adhesion and to reduce inflammation of the equine endometrium (King et al., 1998).

Repeated injections of oxytocin at 0 and 12 to $16 \mathrm{~h}$ after breeding did not improve pregnancy rates of barren mares relative to the control group $(\mathrm{T} 1)$. Similar findings were reported by Rigby et al. (1999) when injection of oxytocin immediately after insemination failed to improve pregnancy rates. Treatment with oxytocin (T2) was intended to stimulate uterine contractility and improve pregnancy rates, especially in susceptible mares. Susceptible mares have been shown to have myometrial contraction of short duration and delayed onset in response to an experimental infection (Troedsson et al., 1993b). However, in this study, pregnancy rates of susceptible mares were not improved by any treatment with oxytocin (T2, T4). Similarly, oxytocin (T2) did not improve pregnancy rates in resistant mares.

Treatment of barren mares with oxytocin (T2) did not affect pregnancy rates. It is possible that pregnancy rates could be improved if oxytocin was injected 4 to $8 \mathrm{~h}$ after breeding (LeBlanc et al., 1994, Rasch et al., 1996). Pregnancy rates of barren mares were improved by infusion of plasma with leukocytes (T3), probably because of an improvement of uterine cellular and humoral immunity.

In lactating mares, greater pregnancy rates were observed in mares treated with plasma with leukocytes (T3) and in untreated mares (T1). This is in agreement with Mattos et al., 1997. Use of oxytocin (T2) reduced pregnancy rates relative to the control group. These results suggest that most lactating mares do not have deficiencies in cellular and humoral immune mechanisms involved in eliminating postbreeding inflammation. 
The use of ecbolic drugs is detrimental to fertility in lactating mares. It is possible that administration of oxytocin immediately after breeding decreased sperm transport to the oviduct. The fact that oxytocin (T2) decreased pregnancy rates in lactating mares, but not in barren mares, may be related to the fact that many barren mares have defects in uterine contractility. Administration of oxytocin in mares with defective contractility may not interfere with sperm transport.

These findings are supported by the results observed in mares bred naturally and in mares artificially inseminated. In inseminated mares, pregnancy rates were lower when animals were treated with oxytocin or with the combination of oxytocin and plasma with leukocytes. In contrast, mares bred naturally treated with any treatment had improved pregnancy rates relative to the control group. Since the number of spermatozoa deposited in the uterus is smaller when mares are inseminated artificially, it is possible that uterine contractions induced by oxytocin cause evacuation of spermatozoa from the uterus to the vagina. When mares are bred naturally, a more intense inflammatory reaction follows because of the greater number of spermatozoa deposited in the uterus (Katila, 1995). It is possible that the use of oxytocin (T2), plasma with leukocytes (T3), or a combination of oxytocin and plasma with leukocytes (T3) result in faster elimination of uterine inflammation either by the myometrial action of oxytocin or by the humoral and cellular action of plasma and leukocytes.

\section{Literature}

Andonegui, G., Trevani, A.S., Lopez, D.H., Raiden, S., Giordano, M. and Geffner, J.R. (1997): Inhibition of human neutrophil apoptosis by platelets. J. Immunol., 158, 3372-3377.

Asbury, A.C. (1987): Failure of uterine defence mechanisms. In: Robinson, N. E. : Current Therapy in Equine Medicine. 2. Ed. Philadelphia, W. B. Saunders, 508-511.

Bracher, V., Gerstenberg, C., Mathias, S and Allen, W.R. (1997): Influence of age and parity on the equine endometrium. Pferdeheilkunde, 13, 549 .

Carnevale, E., Griffen, P. and Adams, G. (1993): Effects of age and the conceptus on uterine morphology and function. Equine Vet. J. 25, 190-191.

Ginther, O.J. (1992): Reproductive biology of the mare: basic and applied aspects. 2nd Ed., Equiservices, Cross Plains, 642

Rigby, S., Hill, J.R., Miller, C.D., Thompson, J., Varner, D.D. and Blanchard, T.R. (1999): Administration of oxytocin immediately after insemination does not improve pregnancy rates in mares bred by fertile or subfertile stallions. Theriogenology, 51, 1143-1150.

Jones, D. (1995): Fluid distribution and cervical loss following intrauterine infusion in the mare. Equine Practice, 17, 12-19.

Katila, T. (1995): Onset and duration of intrauterine inflammatory response of mares after insemination with fresh semen. Biol. Reprod. Mono 1, 515-517

King, S.S., Carnevale, E.M., Nequin, L.G. and Crawford, J.J. (1998): Inhibition of bacterial endometritis with mannose. J. Equine Vet. Sci. 18, 332-334.

Kotilainen, T., Hutinen, M. and Katila, T. (1994): Sperm induced leukocytosis in the equine uterus. Theriogenology, 41, 629-636.

LeBlanc, M.M., Neuwirth, L., Mauragis, D., Klapstein, E. and Tran, T. (1994): Oxytocin enhances clearance of radiocolloid from the uterine lumen of reproductively normal mares and mares susceptible to endometritis. Eq. Vet. J. 26, 109-113.
Liu, I.K.M., Cheung, A.T.W., Walsh, E.M., Miller, M.E. and Lindenberg, P.M. (1985): Comparison of peripheral blood and uterine-derived polymorphonuclear leukocytes from mares resistant and susceptible to chronic endometritis: chemotatic and cell elastimetry analysis. Am. J. Vet. Res. 46, 917-920.

Mattos, R.C., Malschitzky, E., Mattos, R. and Gregory, R.M. (1997): Effects of different postbreeding treatments on fertility of Thoroughbred mares. Pferdeheilkunde, 13, 512-515.

Rasch, H., Schoon, H.A., Sieme, H. and Klug, E. (1996): Histomorphological endometrial status and influence of oxytocin on the uterine drainage and pregnancy rates in mares. Equine Vet. J. 28, 455-460.

Schoon, H.A., Schoon, D. and Klug, E. (1997): Die Endometriumsbiopsie bei der Stute im Klinisch-gynäkologischen Kontext. Pferdeheilkunde, 13, 453-464.

Troedsson, M.H.T. (1997): Therapeutic considerations for mating-induced endometritis. Pferdeheilkunde, 13, 516-520

Troedsson, M.H.T., Steiger, B.N., Ibraihm, N.M., Foster, D.N. and Crabo, B. (1995): Mechanisms of sperm-induced endometritis in the mare. Biol. Reprod. (Suppl.), 52, 307.

Troedsson, M.H.T., Liu, I.K.M. and Thurmond, M. (1993a): Function of uterine and blood-derived polymorphonuclear nutrophils in mares susceptible and resistant to chronic uterine infection: phagocytosis and chemotaxis. Biol Reprod. 49, 507-514.

Troedsson, M.H.T., Liu, I.K.M., Ing, M., Pascoe, J. and Thurmond, M. (1993b): Multiple site electromyography recordings of uterine activity following an intrauterine bacterial challenge in mares susceptible and resistant to chronic uterine infection. J. Reprod. Fert. 99, 307-313.

Vanderwall, D.K. and Woods, G.L. (1992): Age related ovulatory dysfunction. In: Robinson, N. E.: Current Therapy in Equine Medicine.

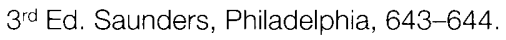

Woods, G.L., Baker, C.B., Badwin, J.L., Ball, B.A., Bilinski, J., Cooper, W.L., Ley, W. B., Mank, E.C. and Erb, H.N. (1987): Early pregnancy loss in brood mares. J. Reprod. Fert. (Suppl.) 35, 455-459.

Zalavary, S., Grenegard, M., Stendhal, O. and Bengtosson, T. (1996): Platelets enhance $F_{C}$ receptor-mediated phagocytosis and respiratory brust in neutrophils: the role of purinergic modulation and actin polimerization. J. Leukcyte Biol. 60, 58-68.

\section{Rodrigo Costa Mattos}

Reprolab

Departamento de Medicina Animal

Faculdade de Veterinária

Universidade Federal do Rio Grande do Sul

P.O. Box 15094

91501-970, Porto Alegre, RS

Brazil

Tel: \#55 513166124

Fax: \#55 513195300

E-mail rcmattos@vortex.ufrgs.br.

\section{Luis Fernando Fiori Castiho}

Medicina Veterinária

AGROPLAC

Universidade do Planalto Central

Brasilia, DF, Brazil.

\section{Ana Luiza Gelpi Mattos}

Departamento de Medicina Veterinária

Centro de Ciáncias da Saúde

ULBRA,

Canoas, RS

Brazil 